$\xi=$

\title{
Shiga toxin (STX) gene analysis and verotoxigenic potentials of Escherichia coli isolated from 'bobozi'- an indigenous Nigerian ready to eat fermented cassava chip
}

\author{
Stephen Amadin Enabulele*, Ebakota Oziengbe Daniel \\ Department of Basic Sciences, Faculty of Basic and Applied Sciences, Benson Idahosa University, Benin City, Edo State, Nigeria \\ *Corresponding author E-mail:amadinbulele@yahoo.com
}

\begin{abstract}
Many strains of $E$. coli have been identified as food borne pathogens inducing serious gastrointestinal diseases and even causing death in humans. Amongst these are those referred to as Shiga or Vero toxin producing E. coli. Bobozi is an Indigenous Nigerian ready to eat snack food made from cassava and is widely consumed in most parts of the country. The objective of this study was to Isolate and Identify E. coli from Bobozi, analyze their Shiga toxin (stx) gene profile and thereafter determine their verotoxin capabilities. A total of 248 samples of Bobozi were purchased from hawkers in the metropolis of Benin City, Edo state, Nigeria. Isolation and Identification was done using standard microbiological methods. Analysis for the presence of Shiga toxin (stxl and stx2) genes was done using PCR technique and for their verotoxigenic potentials using tissue culture assay on Vero cells. Result of the investigation reveals that of the total 248 samples collected, 107(43.15\%) had E. coli isolated from them. Total number of E. coli isolated from the 107 samples was 386.Shiga toxin gene analysis of the isolates reveal that $169(43.78 \%)$ had stxl gene alone, $112(29.02 \%)$ had stx2 gene alone, 3(0.78\%) had both stx 1 and stx 2 genes while $102(26.42 \%)$ had none of the two genes. Tissue culture assay on Vero cells indicate that there is a strong relationship between the presence of stx genes and their degree of cytotoxic effect on vero cells as over $80 \%$ isolates without the genes exhibited weak cytotoxic effect whereas over $80 \%$ of those with the genes exhibited more than strong cytotoxic effect.
\end{abstract}

Keywords: Bobozi; Verotoxins; Escherichia coli; Shiga toxins; Vero cells.

\section{Introduction}

Escherichia coli although are the predominant non-pathogenic facultative flora of the human intestine, some strains are known to have developed the ability to cause disease of the gastrointestinal tract and have been identified as a leading cause of food borne illness all over the world (Hussein, 2007). Amongst these are those referred to as Shiga or Vero toxin producing E. coli. Although most of the reported human illness outbreaks associated with shiga toxin producing $E$. coli have been attributed to the 0157:H7 serotype, reports however indicate that other $E$ coli serotypes implicated in food borne outbreak aside the 0157:H7 posses these genes (ECDC, 2011; Beutin, et al., 2004; Bennett and Bettelheim, 2002).

Bobozi is an Indigenous Nigerian ready to eat fermented snack food made from cassava and is widely consumed in most parts of the country. They are mostly prepared, stored and sold under conditions that can be said to be hygienic. They are either displayed in open trays in the market or hawked along the street and major highways. Contamination with organisms such as E. coli can therefore not be ruled out. Consequent upon the above, this work was done to Isolate and identify E. coli from Bobozi, analyse their vero toxin $(s t x)$ gene profile and determine their verotoxigenic potentials on vero cells

\section{Materials and methods}

\subsection{Isolation and identification of E. coli}

A total of 248 samples of fermented cassava chips (Bobozi) purchased from hawkers in the metropolis of Benin City, Edo state, Nigeria, were mashed in sterile mortar and $1 \mathrm{~g}$ homogenized in $9 \mathrm{ml}$ buffered peptone water. Serial dilutions of up to $10^{-5}$ were then made and $1 \mathrm{ml}$ of each homogenate was then plated on Eosin methylene blue (EMB) agar and incubated at $37^{\circ} \mathrm{C}$ for $24 \mathrm{~h}$. Pure cultures of all colonies exhibiting typical dark to purple colonies with metallic sheen which is characteristic of E. coli on EMB were then made in readiness for biochemical tests. Biochemical tests to confirm E. coli was done using the API 20 E test strips and in accordance with the method described by Holt et al. (1994).

\subsection{Screening for shiga toxin (stx 1 and 2)}

Analysis for the presence of Shiga toxin (stx1 and stx2) genes was done using PCR technique with primers manufactured by Primerdesign Ltd, UK, targeting the stx 1 and stx 2 genes according to method outlined by Blanco et al. (2003).DNA extraction was done according to Sambrook and Russell, (2001). The mixture for the amplification of $s t x 1$ and stx 2 genes consisted of $2.5 \mu 1$ of PCR buffer $(10 \mathrm{mM}$ Tris- $\mathrm{HCl} \mathrm{pH} 9,50 \mathrm{mM} \mathrm{KCl}$, and $0.1 \%$ Triton X100), $2.5 \mathrm{mM} \mathrm{MgCl}, 0.2 \mathrm{mM}$ of each dNTP, $1 \mu \mathrm{M}$ of each primer and $1.25 \mathrm{U}$ of Taq polymerase, in a final volume of $25 \mu 1$. Amplifi- 
cation was done with a 96 well dual head Pelter thermocycler (DNA engine) model PTC-200. The amplification conditions consisted of an initial denaturation step at $94^{\circ} \mathrm{C}$ for $4 \mathrm{~min}$, and 30 cycles of $94^{\circ} \mathrm{C}$ for $1 \mathrm{~min}$ (denaturation), $55^{\circ} \mathrm{C}$ for $1 \mathrm{~min}$ (annealing), and $72^{\circ} \mathrm{C}$ for $1 \mathrm{~min}$ (extension), and a final step at $72^{\circ} \mathrm{C}$ for $10 \mathrm{~min}$. PCR products were analyzed by electrophoresis on $1 \%$ agarose gel and visualized by ethidium bromide staining in a UV trans-illuminator.

\subsection{Tissue culture assay for verotoxin production}

Preparation of extract for tissue culture assay was done by firs inoculating pure cultures of all test isolates maintained on nutrient agar slants in $5 \mathrm{ml}$ Trypticase soy broth (TSB) and incubated overnight at $37^{\circ} \mathrm{C} .500 \mu 1$ of the inoculated Trypticase soy broth was then transferred onto $5 \mathrm{ml}$ brain heart infusion broth (BHIB) and incubated at $37^{\circ} \mathrm{C}$ for $24 \mathrm{~h}$. Extract filtrate was obtained by first centrifuging $1 \mathrm{ml}$ of the incubated BHIB at $4000 x g$ using a Gemmyco centrifuge model PLC-025 to reduce debris and aid filtration. The supernatant was then passed through a $0.20 \mu \mathrm{m}$ pore-size titan two $30 \mathrm{~mm}$ diameter nylon membrane syringe filter supplied by SMI-LabHut Ltd UK. Sterility check was done on all filtrate by plating an aliquot of the filtrate on MacConkey agar and incubated overnight at $37^{\circ} \mathrm{C}$. Plates showing no growth were considered sterile. The BHIB filtrates were screened for verocytotoxicity by using a modified method of Rahn et al. (1996).Filtrate was used to cause swelling, rounding or dissemination of vero cells prepared by passaging on monolayer in 96 well micro titre plates.

Vero cells for the cell culture assay was prepared by trysinizing with 1X trypsin - EDTA and seeded in 96 well flat bottom micro titre plate at $4 \times 10^{5} /$ well and using $1 \%$ Glasgow Minimum Essential Medium (GMEM) with addition of Hepes buffer as the growth medium. Growth medium was replaced with fresh GMEM after aspiration before cells were infected with filtrate. Undiluted $100 \mu 1$ of the filtrate was transferred to the first well of each plate containing the vero cells and 1:2dilutions in each of the subsequent wells (i.e. $100 \mu 1,50 \mu 1,25 \mu 1,12.5 \mu 1,6.25 \mu 1$ and $3.125 \mu 1$ ) were then done. The plates were incubated at $370 \mathrm{C}$ and examined for verotoxigenic activity after $3 \mathrm{hrs}, 6 \mathrm{hrs}, 12 \mathrm{~h} 24 \mathrm{~h}$ and $48 \mathrm{~h}$ using an inverted microscope. Degree of verotoxigenic effect on each of the vero cells were noted and recorded after each examination. Picture of each well was taken before and after infection. Wells containing less than $25 \%$ cytotoxic effect after $48 \mathrm{~h}$ end point were considered weak, greater than $25 \%$ but less than $50 \%$ fairly strong, greater than $50 \%$ but less than $75 \%$ strong, greater than $75 \%$ but less than $90 \%$ very strong and greater than $90 \%$ excellently strong. Tissue culture assay was done at the Morbilic and Related Virus Laboratory, National Veterinary Research Institute (NVRI), Vom, Jos Nigeria.

\section{Results}

Result of the investigation reveal that of the total 248 samples collected, 107(43.15\%) had E. coli isolated from them. Total number of $E$. coli isolated from the 107 samples was 386 . Shiga toxin gene analysis of the isolates reveal that $169(43.78 \%)$ had stx1 gene alone, $112(29.02 \%)$ had stx2 gene alone, 3(0.78\%) had both stx 1 and stx 2 genes while $103(26.42 \%)$ had none of the two genes. Tissue culture assay on Vero cells indicate that there is a strong relationship between the presence of stx genes and their degree of cytotoxic effect on vero cells as over $80 \%$ isolates without the genes exhibited weak cytotoxic effect whereas over $80 \%$ of those with the genes exhibited more than strong cytotoxic effect.
Table 1: Prevalence of E. coli in Bobozi Sold in Benin City Metropolis

\begin{tabular}{llll}
\hline $\begin{array}{l}\text { Sampling Loca- } \\
\text { tion }\end{array}$ & $\begin{array}{l}\text { Samples collect- } \\
\text { ed }\end{array}$ & $\begin{array}{l}\text { No. }(\%) \text { with } \\
\text { E. coli }\end{array}$ & E. coli isolated \\
\hline Ikpoba hill & 58 & $32(55.17)$ & 94 \\
Kings Square & 66 & $21(31.82)$ & 109 \\
Sapele Road & 61 & $17(27.87)$ & 78 \\
Ugbowo & 63 & $37(58.73)$ & 105 \\
Total & 248 & $107(43.15)$ & 386 \\
\hline
\end{tabular}

Table 2: Shiga Toxin (Stx) Gene Analysis of E. coli Isolates from Bobozi

\begin{tabular}{|c|c|c|c|c|c|}
\hline Location & $\begin{array}{l}\text { No. of } \\
\text { Isolates } \\
\text { Tested }\end{array}$ & stxl only & stx 2 only & st $1 \& 2$ & No stx \\
\hline $\begin{array}{l}\text { Ikpoba } \\
\text { Hill }\end{array}$ & 94 & $42(45 \%)$ & $29(31 \%)$ & $1(1.01 \%)$ & $\begin{array}{l}22 \\
(66 \%)\end{array}$ \\
\hline $\begin{array}{l}\text { Kings } \\
\text { Square }\end{array}$ & 109 & $39(36 \%)$ & $27(25 \%)$ & Nil & $43(72 \%)$ \\
\hline $\begin{array}{l}\text { Sapele } \\
\text { Road }\end{array}$ & 78 & $31(40 \%)$ & $18(23 \%)$ & $1(1.3 \%)$ & $\begin{array}{l}28 \\
(64 \%)\end{array}$ \\
\hline Ugbowo & 105 & $57(54 \%)$ & $38(36 \%)$ & $1(0.95 \%)$ & $9(67 \%)$ \\
\hline Total & 386 & $169(44 \%)$ & $112(29 \%)$ & $3(0.78 \%)$ & $\begin{array}{l}102 \\
(26 \%)\end{array}$ \\
\hline
\end{tabular}

Table 3: Verotoxin Potentials of E. coli Isolates from Bobozi Degree of Verotoxigenicity

\begin{tabular}{|c|c|c|c|c|c|c|}
\hline \multirow[b]{2}{*}{$\begin{array}{l}\text { Shiga } \\
\text { toxin }\end{array}$} & \multicolumn{6}{|c|}{ Degree of Verotoxigenicity } \\
\hline & $\begin{array}{l}\text { No. } \\
\text { Test- } \\
\text { ed }\end{array}$ & $\begin{array}{l}\leq 25 \% \\
\text { (Weak } \\
\text { cyto- } \\
\text { toxic } \\
\text { effect) }\end{array}$ & $\begin{array}{l}\text { Btw } 26 \\
\text { and } \\
50 \% \\
\text { (Strong } \\
\text { cyto- } \\
\text { toxic } \\
\text { effect) }\end{array}$ & $\begin{array}{l}\text { Btw } 51 \\
\text { and } \\
75 \% \\
\text { (Very } \\
\text { strong } \\
\text { cyto- } \\
\text { toxic } \\
\text { effect) }\end{array}$ & $\begin{array}{l}\text { Btw } 76 \\
\text { and } \\
90 \% \\
\text { (Very } \\
\text { very } \\
\text { strong } \\
\text { cyto- } \\
\text { toxic } \\
\text { effect) }\end{array}$ & $\begin{array}{l}>90 \% \\
\text { Excel- } \\
\text { lently } \\
\text { strong } \\
\text { cytotoxic } \\
\text { effect }\end{array}$ \\
\hline $\begin{array}{l}\text { stx1 } \\
\text { only }\end{array}$ & 169 & $\begin{array}{l}26(15 \% \\
)\end{array}$ & $\begin{array}{l}78(46 \% \\
)\end{array}$ & $\begin{array}{l}52(31 \% \\
)\end{array}$ & $13(8 \%)$ & Nil \\
\hline $\begin{array}{l}\text { stx2 } \\
\text { only }\end{array}$ & 112 & $8(7 \%)$ & $\begin{array}{l}47(42 \% \\
)\end{array}$ & $\begin{array}{l}33(30 \% \\
)\end{array}$ & $\begin{array}{l}19(17 \% \\
)\end{array}$ & $5(4 \%)$ \\
\hline $\begin{array}{l}\text { stx } 1 \& \\
2\end{array}$ & 3 & Nil & Nil & Nil & $2(67 \%)$ & $1(33)$ \\
\hline $\begin{array}{l}\text { No } \\
\text { stx }\end{array}$ & 102 & $\begin{array}{l}81(79 \% \\
)\end{array}$ & $19(19 \%$ & $2(2 \%)$ & Nil & Nil \\
\hline
\end{tabular}

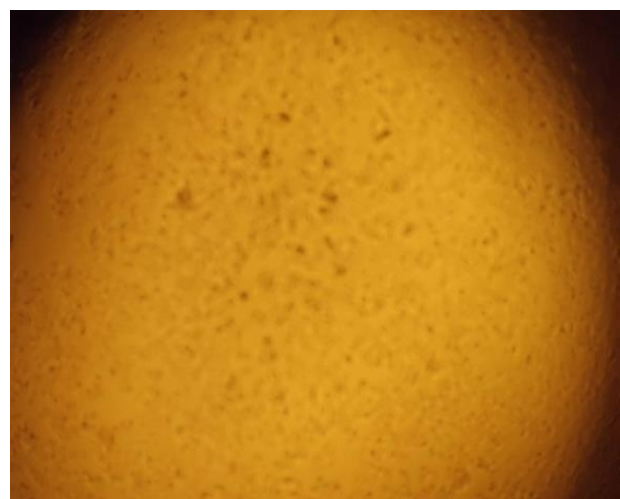

Fig. 1: Uninfected Vero cells still intact at both beginning and end of experiment.

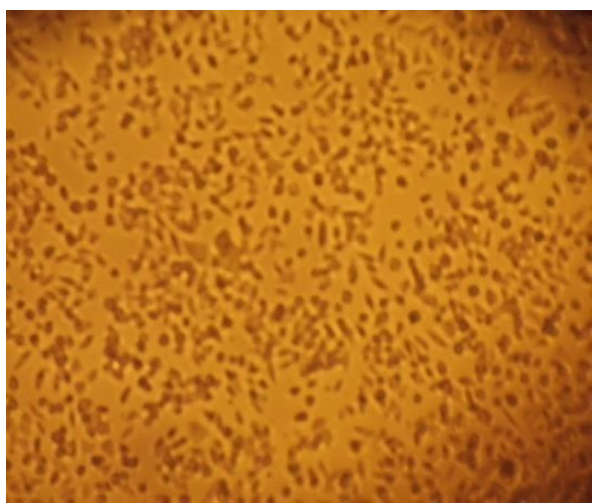

Fig. 2: Infected cells exhibiting rounding and clumping one hour after infection with toxin. 


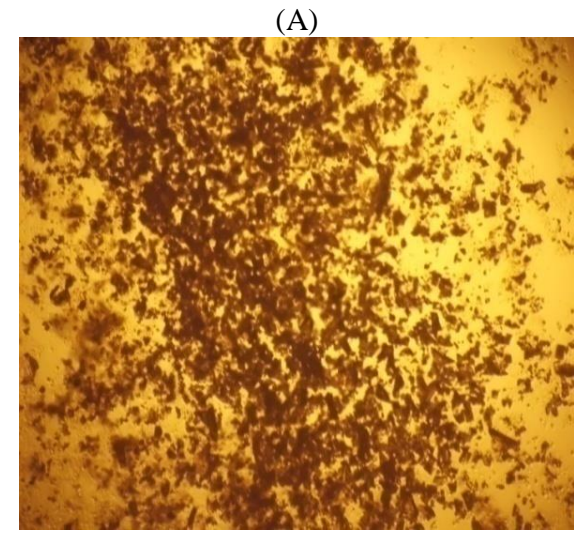

(B)

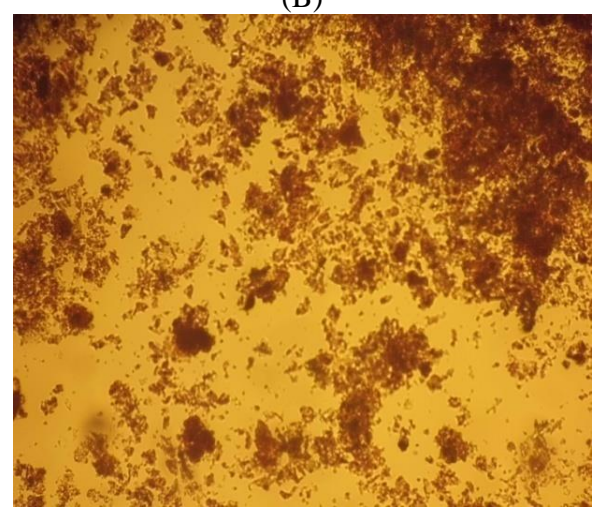

Fig. 3:A and B: Infected Vero cells showing very high degrees of cytotoxic effect on it with the Vero cells detached and completely being eroded at the end of experiment

\section{Discussion}

Safe food is very basic to the human population and knowing that the food we eat is safe are key to ensuring good health of the populace. Ready-to-eat foods offers an easy access to obtaining energy for man's daily activity because they are readily available and does not require further processing before they are consumed. They are also relatively cheap and accessible (Mensah et al., 2002; Oranusi and Braide, 2012).Ready to eat foods however have variously been identified as source(s) of transmission of infectious diseases, resulting in various degrees of illness or even death (Egan et al. (2007).This work was done to Isolate and identify $E$. coli a potential pathogenic microorganism from Bobozi, analyse their vero toxin (stx) gene profile and determine their verotoxigenic potentials on vero cells. The result reveal that an appreciable number of samples $(43.15 \%)$ collected and analysed had the microorganism. E. coli basically are normal flora of the gastrointestinal tract; however some strains have developed the ability to cause diseases of various pathogenic themes. Amongst these are those referred to as Shiga or Vero toxin producing E. coli.

Disease caused by Shiga toxin-producing Escherichia coli (STEC) is known to range from self-limiting diarrhoea to hemorrhagic colitis and haemolytic uremic syndrome (HUS). The O157:H7 serotype is reported to be the most frequently implicated STEC causing hemorrhagic colitis and HUS and it has been isolated from large food borne outbreaks, as well as sporadic cases, in various parts of the world. Although the O157:H7 serotype is not the focus of the work, it is pertinent to mention that the serotype have previously been isolated by this author from some food sources in Nigeria (Enabulele and Uraih, 2009; Enabulele et al. 2014).Over 60 STEC serotypes have been implicated in diarrheal disease, and several non-O157:H7 serotypes have also been implicated as the cause of food borne outbreaks and HUS in the United States, Europe, and Australia. Studies from Canada, Europe, Argentina, and Australia suggest that non-O157:H7 STEC infections are as prevalent, or more so, than O157:H7 infections (Fey et al., 2000).
Kaplan et al. (1990) reported that although STEC produce other accessory virulence factors, such as intimin (eae) and 'enterohemolysin A (ehxA), Shiga toxins 1 and 2 are the main virulence factors associated with hemorrhagic colitis and HUS, presumably because they interact with endothelial cells at the site of infection and in the glomeruli and arterioles of the kidney. They also reported that Stx 1 and Stx 2 are highly related yet immunologically distinct. Analysis of $E$. coli isolated in this study, shows those with stx 1 alone $(43.75 \%)$ to be more while only $0.78 \%$ of $E$. coli isolated from bobozi had both genes. E coli 0157:H7 which is reported to be the most associated with most STEC outbreak and considered to be very virulent is known to harbour both genes (Gyles, 2007). In spite of the fact that STEC 0157:H7 is reported to be the most virulent; series of STEC outbreaks have identified the non 0157:H7 serotypes like 026:H11, O103:H2, O111:NM, O121:H19, O145:NM which may not harbour both genes, but only one of the genes to also be very virulent (Mathusa et al., 2010). They opined that various virulence factors are involved in nonO157 STEC pathogenicity; which included the combined presence of both eae and stx genes.

The use of tissue culture assay on Vero cells is one very important method for confirming verotoxin production in microorganism. The profound sensitivity of Vero cells to shiga- toxins (stx)was first observed by Konowalchuk et al., (1977) and cytotoxicity to this cell line has remain a gold standard for confirming putative shiga- toxin producing isolates. This is because Vero cells have a high concentration of globotriaosylceramide (Gb3) and globotetraosylceramide $(\mathrm{Gb} 4)$ toxin binding receptors in their plasma membranes and will detect all variants of verotoxins. Tissue culture assay on Vero cell to confirm their verotoxigenic capabilities (Plates 1 to 3 ) in this study show a strong correlation between the presence of st $x$ and their degree of verotoxigenicity (table 3). Over $80 \%$ isolates without the genes exhibited weak cytotoxic effect while over $80 \%$ of those with the genes exhibited more than strong cytotoxic effect. The result is in agreement with earlier report by Enabulele et al., (2014) on E. coli $0157: \mathrm{H} 7$. The result also is an indication of the fact that presence of stx is a determining factor is the virulence of the Shiga toxin producing E. coli. Rahn, et al.(1996), in their Comparison of Vero cell assay (VCA) and Polymerase chain reaction( PCR) assay as indicators of the presence of verocytotoxigenic Escherichia coli in bovine and human faecal samples, report that although correlation between VCA and PCR results was not absolute, when used in conjunction, these tests complemented one another as predictors of STEC isolation.

\section{Conclusion}

Conclusively, the findings from this study provide evidence of the presence of Shiga toxin producing $E$. coli in our food system. It is of significant public health importance, especially as its consumption with food can be of serious health challenge. Verotoxigenic E. coli sub-strains have already been found in some other countries to be responsible for serious food borne infection outbreak (Nataro and Kaper, 1998), and the fact that Bobozi is a Ready to eat snack food that is consumed without further processing. The product is also observed to be widely consumed in Nigeria especially by people of the three southern geopolitical regions of south south, south east and south west, and also in major parts of the middle belt region. It is recommended therefore that more measures be taken in monitoring the processing and sale of such food products to prevent potential food borne disease outbreak in the country.

\section{References}

[1] Bennett J. and Bettelheim K. A. (2002). Serotypes of non-O157 verocytotoxigenic Escherichia coli isolated from meat in New Zealand. Comp Immunol Microbiol Infect Dis. 25(2):7784http://dx.doi.org/10.1016/S0147-9571(01)00024-8.

[2] Beutin L, Krause G, Zimmermann S, Kaulfuss S, Gleier K. (2004). Characterization ofShiga toxin-producing Escherichia coli strains isolated from human patients in Germany over a 3-year period. $J$ 
ClinMicrobiol

42(3):1099-

108http://dx.doi.org/10.1128/JCM.42.3.1099-1108.2004.

[3] Blanco M., Blanco J.E., Mora A., Ray J., Alonso J. M., Hermoso M., Hermoso J., Alonso M.P., Dhabi G., Gonzalez E. A., Bernardez E. I. and Blanco J.(2003). Serotypes, virulence genes and intimin types of Shiga toxin (verotoxin) producing Escherichia coli isolates from healthy sheep in Spain. J. Clin. Microbiol. 42: $645-$ 651.http://dx.doi.org/10.1128/JCM.42.2.645-651.2004.

[4] Egan, M.B., Raats, M.M., Grubb, S.M., Eves, A., Lumbers, M.L., Dean M.S. and Adams, M.R. (2007). A review of food safety and food hygiene training studies in the commercial sector. Food Con18:

1180 1190.http://dx.doi.org/10.1016/j.foodcont.2006.08.001.

[5] Enabulele, S. A. and Uraih, N. (2009). Enterohaemorrhagic Esche richia coli 0157:H7Prevalence in meat and vegetables sold in Benin City, Nigeria. Afri. J. of Microbiol. Res. 3(5): 276-279.

[6] Enabulele S.A., Eghafona N.O. and Dahiru M.(2015). Molecula Characterisation and Verotoxigenic Potentials of Enterohaemorrhagic Escherichia coli 0157:H7 Isolated from Fermented Fresh Cow Milk (Nunu) sold in Selected Cities in Nigeria. BIU Journal of basic and Applied Sciences. 1(1): 51-62.

[7] European Centre for Disease Prevention and Control and European Food Safety Authority (ECDC) (2011). Shiga toxin/verotoxinproducing Escherichia coli in humans, food and animals in the EU/EEA, with special reference to the German outbreak strain STEC O104. Stockholm.

[8] Fey, P. D., Wickert, R. S., Rupp, M. E., Safranek, T.J. and Hinrichs, S.H. (2000). "Prevalence of Non-O157:H7 Shiga ToxinProducing Escherichia coli in Diarrheal Stool Samples from Nebraska" Public Health Resources. Paper 21. http://digitalcommons.unl.edu/publichealthresources/21.

[9] Gyles C. L. (2007). Shiga toxin- producing Escherichia coli: An overview. J. Anim. Sci. 85: E45E62http://dx.doi.org/10.2527/jas.2006-508.

[10] Holt, J. G, Krevy, H. S, Sneathe, R. H. A, Williams S. T. (1994) Bergey's Manual of Determinative Bacteriology 9th Edition. Williams and Wilkens Company, Baltimore, USA.

[11] Hussein H. S. (2007). Prevalence and Pathogenicity of Shiga- toxin producing Escherichia coli in beef cattle and their products. $J$. Anim. Sci. 85: E63-E72.http://dx.doi.org/10.2527/jas.2006-421.

[12] Kaplan B. S, Cleary T. G, Obrig T. G. (1990). Recent advances in understanding the pathogenesis of the haemolytic uremic syndrome. Pediatr Nephrol. 4: 276-83.http://dx.doi.org/10.1007/BF00857676.

[13] Konowalchuk, J., Speirs, J. I., and Stavric, S. (1977). Vero response to a cytotoxin of Escherichia coli. Infect. Immun. 18:775-779.

[14] Mathusa E. C., Chen Y., Enache E. Hontz L. (2010). Non-O157 Shiga toxin producing Escherichia coli in foods. J. Food Prot. 73(9):1721-36

[15] Mensah, P., Yeboah, M. D., Owusu, D. K. and Ablordey, A (2002). Street foods in ACCRA, Ghana: how safe are they? Bulletin of the World Health Organization 80(7): 546-554

[16] Nataro, J. P. and Kaper J. B. (1998). Diarrheagenic Escherichia coli Clin. Microbiol. Rev. 11: $142-201$

[17] Oranusi, U. S. and Braide, W. (2012). A study of microbial safety of Ready-to-eat foods vended on highways: Onitsha-Owerri, south east Nigeria. International Research Journal of Microbiology 3(2):006-071.

[18] Rahn K., Wilson J. B. Mcfadden K. A. Read S. C. Ellis A G.Renwick S. A., Clarke R. C and Johnson R. P.(1996). Comparison of Vero Cell Assay and PCR as Indicators of the Presence of Verocytotoxigenic Escherichia coli in Bovine and Human Fecal Samples. Appl. Environ. Microbiol. 62(12): 4314 - 4317.

[19] Sambrook J. and Russell, D. W.(2001). Molecular cloning: A Laboratory Manual vol 2. Cold Spring Habour Lab. Press New York. p126. 